will endeavour to appraise a problem and give a considered answer whatever its implications. Asked to do things, he gets them done-and with the department's thinking complete, a 'doer' is what it has needed and still demands. $\mathrm{He}$ will be a loss in that respect alone. Mr Benn is different. He must be happy with Marshall's record in executing R\&D. But he would have found Marshall irritating to have around with nuclear matters such a big preoccupation. As an ideas man and a political animal to the core, moreover, he needs advisers to brainstorm with who are well-versed politically. And he needs them full-time. Marshall was no intellectual dilletante, and wasn't full-time. Benn is no scientist. And he may not want to get things done.

This other point, that delays are costly, is also important; $\mathrm{Mr}$ Benn's advisers have long been urging that decisions be taken. On the other hand, however, the nuclear pause, as Mr Benn calls it, is a bind for bureaucrats, who need goals and the work goals provide-and the nuclear field is a huge chunk of the department's landscape. The industry, too, wants decisions. Now it may well be that in favouring delay for the sake of a public debate Mr Benn has encouraged confrontation, and sought only to ride the back of a good issue for his own personal advancement. But to attribute motives of personal political convenience to actions that have helped to put a complacent industry properly on its toes may be unkind.

Suppose, then, that there may be a good deal in what $\mathrm{Mr}$ Benn himself says about now wanting an adviser who can range over the full spectrum of energy matters full-time. If Marshall's nuclear and non-nuclear experience doesn't equip him to do just that, and if it isn't enough simply to speak of Marshall as having suddenly become an unacceptable irritant, there must be a problem above and beyond the fact that to appoint Marshall to a full-time post as adviser would be a rebuff for Sir John Hill. Indeed, not to have made Marshall full-time adviser with a brief ranging over all fields is again a humiliation.

What could this other reason have been? The suddenness of the announcement suggests that the decision was not thought out. But it had apparently been brewing for some time. So perhaps it is better to look at things from the other side. Although it may really be better to announce decisions like this than have them leak out, not announcing a replacement, and saying that an official is to leave 'as

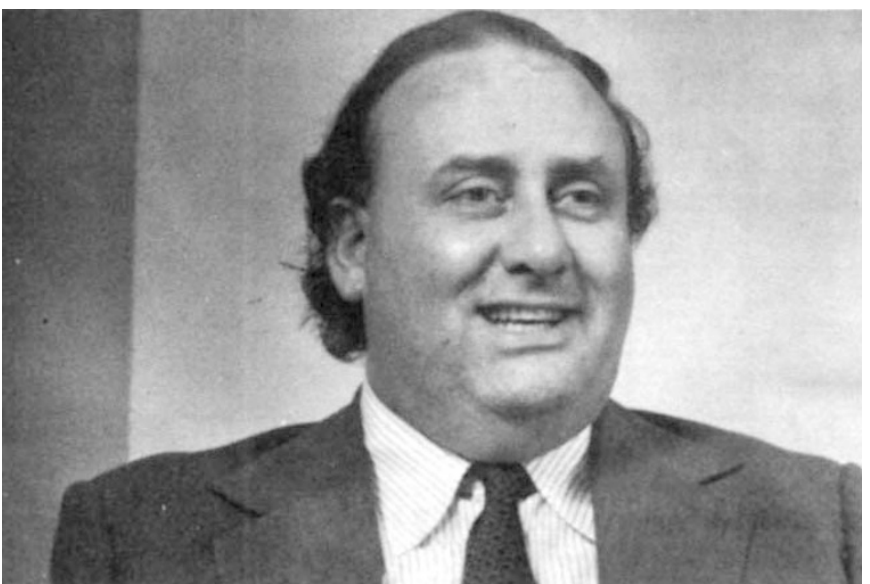

Marshall : did he fall or was he pushed?

soon as possible', is unusual. A presumption has to be made that a replacement will be anounced shortly.

That, however, is difficult to do by recruiting from outside civil service ranks, and certainly cannot be done quietly. It is thus more likely that the post will be filled by someone already available. The obvious place to look is among the other chief scientists. Apparently $\mathrm{Mr}$ Benn wants another chief scientist as his adviser. And the one who has the necessary experience and who might fit Mr Benn's requirements - more than any other-is Sir Hermann Bondi, chief scientist at the Ministry of Defence. No one else is in sight, and Bondi, having done six years in his present post and being a greater believer in a varied diet, might well find the move attractive.

If that happens, plenty of people would welcome it, not least various people at the Ministry of Defence itself. So one would wonder whether the whole operation was perhaps set up before Marshall's departure was announced. If so, Mr Benn's advocacy of open goverment, sincere as it is, looks thinner as a consequence. More importantly, his experiences with Monty Finniston, Arthur Hawkins and now Walter Marshall suggest that he has a reputation for not being able to get on with his advisers. With such important decisions looming, that is the biggest worry of all.

\title{
The concept of usefulness
}

Among other things, UK research councils are expected to support 'useful' research. In an article based on a lecture given at the Rutherford High Energy Laboratory, Sir Alec Merrison, Vice-Chancellor of Bristol University, comments

ScIENTISTS and society interact in many ways and the interaction is mediated by many agencies. The principal mediating agency in the UK is the government and in turn the government entrusts a great part of its mediating role to the research councils. Society makes demands of scientists and scientists make demands of society and in recent years these demands in both directions have become large.

In the past 15 or 20 years there has been a marked contrast between the mood of society in this country, very much determined by the sense of national failure, and the mood of science everywhere, which has been extremely buoyant. So government has looked to science (and technology) to be 'useful' and this was very much in the mind of the Labour government when it came to power in 1964 and again in the mind of the Tory government of 1970 .

It is important to understand that the concept of use- fulness is a decidedly limited one when applied to research, indeed it has to be applied with a good deal of taste. It is easy to identify certain research which will probably be useless in the economic sense, and just as easy to identify research which will certainly be useful. But these are limited areas and in between there is a vast body of research whose usefulness it is difficult, if not impossible, to quantify. Look at how much the world has been changed by the discovery 45 years ago of the neutron, and think how much it might be changed in the next 20 years or so by the discoveries of molecular and cell biology. But governments, and a fortiori ministers, do not last for 45 (or even 20 ) years and so, for this and other more compelling reasons, the time-scale is all-important in judging usefulness.

There have been two major revolutions in the past 15 years in the way research councils work: the one set in motion by the Trend Report of 1963 and the one flowing from the White Paper A Framework for Government Research and Development in 1972. It was on the Trend Report and the consequent Science and Technology Act of 1965 that our present framework of five research councils has been based. But one of Trend's recommendations, pro- 
posing the creation of an Industrial Research and Development Association, was inflated by the then new Labour Government into the now defunct Ministry of Technology. The aim of the 1965 Act was to bring some rationalisation and coherence to the civil research sponsored by public funds, and this it certainly did. But it was a recurrent theme through the 1960s that the research councils were not paying sufficient heed to the nation's needs, insofar as these were expressed by the government's spending departments. In 1970 this found expression in a bid by the Ministry of Agriculture to take over the Agricultural Research Council. This matter was examined by a committee of civil servants, chaired by Mr S. P. Osmond, who recommended that it should happen. Before agreeing, the then Secretary of State for Education and Science asked the Council for Scientific Policy, whose remit it was to advise her on all matters concerning the research councils, to advise her "on the most effective arrangements for organising and supporting pure and applied scientific research and postgraduate training". A small working party under the CSP Chairman, Sir Frederick Dainton, reported to her in May 1971 that its view was that the research councils should be left largely untouched but that the CSP itself should be reformed so that account could be taken of the views on policy held by government departments.

Just after this report was submitted, Lord Rothschild was appointed as first head of the Central Policy Review Staff and the government asked him to review the management of the whole of government research and development including that falling within the purview of the research councils. Lord Rothschild enunciated his now famous 'customer-contractor principle' which was to be applied to all research and development other than basic research. He recommended that in the case of three of the five research councils (Agriculture, Medicine and Natural Environment) there should be a large transfer of their funds to those departments which had an interest in their work. The departments would then use the research councils as their contractors to carry out work which they commissioned.

In the White Paper of July 1972 the government decided that the CSP should indeed be reformed, largely along the lines suggested by the Dainton Committee, and thus it became the Advisory Board for the Research Councils. They accepted too a modified form of Rothschild's customer-contractor principle and his proposal to transfer funds (roughly $50 \%$ from the ARC, $30 \%$ from NERC and $25 \%$ from the MRC). It is perhaps unnecessary to say that rather elaborate machinery has inevitably had to be set up to supervise the allocation of this transferred money.

There are three questions which can be asked in the case of each of these major reforms. Has it made any difference? Has it done society any good? Has it done scientists any good? Now is certainly the right time to ask these questions, since it was the Tory Government's intention when they published their 1972 White Paper that at least five years should elapse before any further substantial change should be contemplated. But in answering them it must be borne in mind that they are essentially questions which are not only difficult to answer, if indeed they can be answered, but also that any answers which can be offered must contain a good deal of subjective judgment.

Both reforms have certainly made a difference and I would imagine that this at least is an answer which would arouse little dissent. So far as the 1965 Act is concerned my own view is that both society and scientists have benefited. A reasonably flexible system has been created which at the same time is sufficiently cohesive that the 'Science Vote' is a good way to control the funds at the disposal of the research councils (not that they are ever enough!).

We are still rather close to the 1972 reforms, but five years later it is difficult to see that they have had any really substantial effect, and such effect that they have had seems to have been for the worse. They have certainly not done the scientists any good, but neither have they done them very much harm (with the possible exception of a good deal of nervousness on the part of scientists working in the more fundamental areas).

What has unquestionably happened is that an unnecessarily elaborate machine has been set up to supervise the spending of the money transferred from the research councils to government departments. This is certainly a loss to both scientists and society and should be reformed. It is wasteful of people's time and is yet another piece of inefficient bureaucracy.

Equally unquestionably, what has not happened is a re-direction of research to any conspicuous degree. One can ascribe this to the incorrigible waywardness of scientists or to the fact that they were not after all quite so insensitive to the needs of society as some people believed. My own view would be that it is largely the latter. At any rate, society is on balance the loser because of the 1972 reforms.

One of the weaknesses of the transferred money system is that once the control of a budget gets into the hands of a spending department then that budget will be at the hazard of all sorts of departmental pressures, few of which will have anything ito do with whether the research which might be funded is good or bad. I can hardly believe that last year, when the DHSS decided not to spend nearly a million pounds of its transferred money, it took the decision simply on the grounds that it had come to the conclusion that it was not getting value for money.

So it is a good time to examine carefully the benefits and disadvantages of this way of government departments and research councils working together and, if it really is more trouble than it is worth, to scrap it. It would be good to look too at the whole conspectus of the government's support of 'useful' research and see whether the balance is right. Are we spending the right relative sums on aeronautical research and civil engineering, for example? But if any review is to be undertaken, on a narrow or broad front, I very much hope the reviewers bear in mind the fragile nature of the concept of usefulness in this field.

UK Research Councils: Where they fit

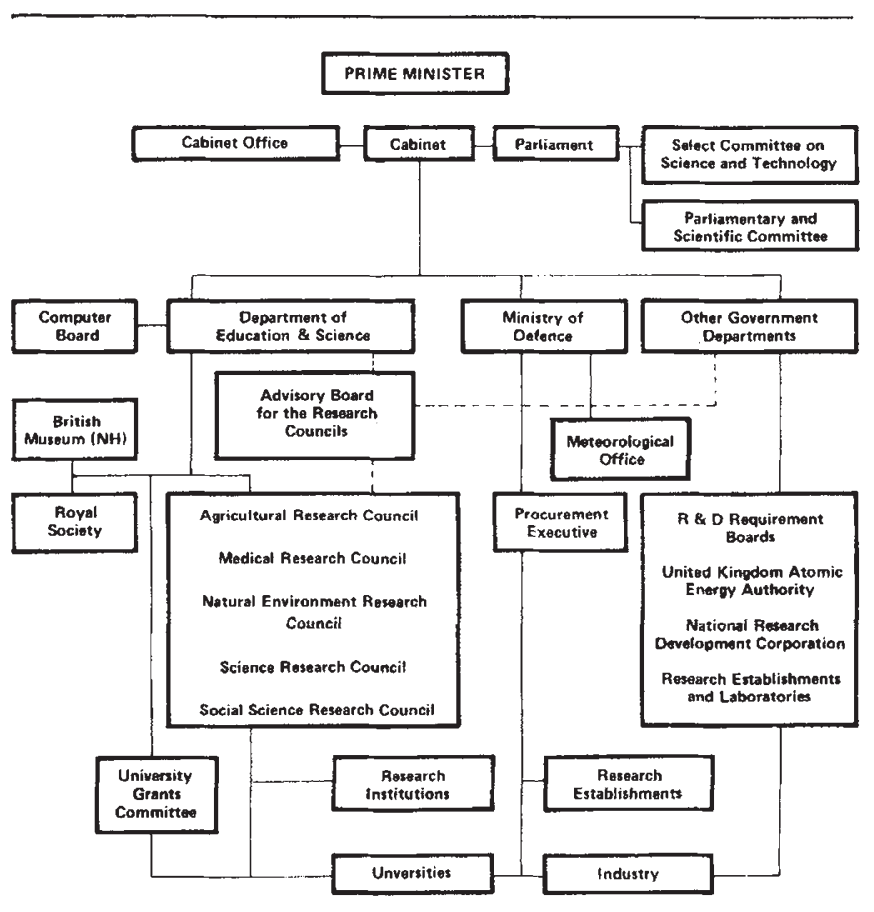

